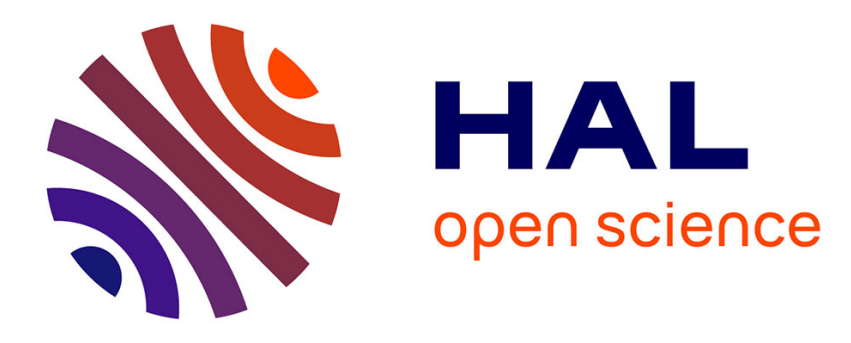

\title{
The Nationalization of Algerian Football following Independence, 1962-1982
}

\author{
Stanislas Frenkiel
}

\section{To cite this version:}

Stanislas Frenkiel. The Nationalization of Algerian Football following Independence, 1962-1982. International Journal of the History of Sport, 2021, 38 (9), pp.972-987. 10.1080/09523367.2021.1974404 . hal-03494271

\section{HAL Id: hal-03494271 https://hal-univ-artois.archives-ouvertes.fr/hal-03494271}

Submitted on 5 Jan 2022

HAL is a multi-disciplinary open access archive for the deposit and dissemination of scientific research documents, whether they are published or not. The documents may come from teaching and research institutions in France or abroad, or from public or private research centers.
L'archive ouverte pluridisciplinaire HAL, est destinée au dépôt et à la diffusion de documents scientifiques de niveau recherche, publiés ou non, émanant des établissements d'enseignement et de recherche français ou étrangers, des laboratoires publics ou privés. 


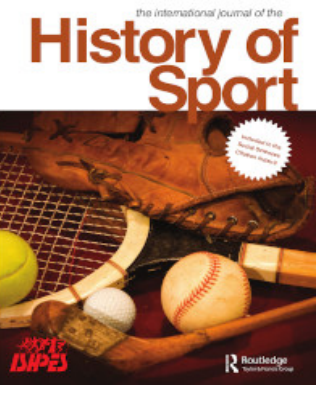

\section{The International Journal of the History of Sport}

\section{The Nationalization of Algerian Football following Independence, 1962-1982}

\section{Stanislas Frenkiel}

To cite this article: Stanislas Frenkiel (2021) The Nationalization of Algerian Football following Independence, 1962-1982, The International Journal of the History of Sport, 38:9, 972-987, DOI: 10.1080/09523367.2021.1974404

To link to this article: https://doi.org/10.1080/09523367.2021.1974404

\section{Published online: 01 Oct 2021.}

Submit your article to this journal $₫$

山ll Article views: 17

Q View related articles $\widetilde{ }$

View Crossmark data $₫$ 


\title{
The Nationalization of Algerian Football following Independence, 1962-1982
}

\author{
Stanislas Frenkiel \\ Department of Sports and Physical Education, University of Artois, Liévin, France
}

\begin{abstract}
Ever since the rise of professionalism in 1932, more than 500 Algerian footballers have taken part in the National Championship of France. Their story is the result of a common, troubled period. Based on the cross-referencing of written and oral sources collected in France, Switzerland and Algeria, including approximately sixty interviews with former professional Algerian players from all generations, the focus of this study is the brutal nationalization of Algerian football after independence. How did Algerian politics affect elite football? What were the consequences for sports migration between two countries linked by a long and bloody colonial history? Starting in 1962, civilian and military clubs and teams were strictly controlled by the Algerian State and Football Association. For political reasons, related to the prestige of Algeria as a nation, players were often not allowed to migrate, or to be selected to wear the colours of Algeria. The intention of this article is to analyse the role of football in the construction of the nation of Algeria after 1962. Football helped put Algeria on the map despite a lack of involvement and representation by African nations in the main decision-making instutions of football, notably FIFA.
\end{abstract}

KEYWORDS

Football;

Algeria;

independence;

nationalism;

migration;

politics;

socialism

\begin{abstract}
A bundle of Algerian flags is waving and snapping in the winds of history, which has now reached a tipping point. All these anonymous faces offer us the sight of a land bathed in a harsh and raw sunlight. They reveal to us a world which is no more, recording on film this "French Algeria" -which in so many ways was anything but French- and which was in the process of vanishing before our very eyes. ${ }^{1}$
\end{abstract}

Besides the National Liberation Front (FLN) team, since the colonial period, Algerian nationalists have used football for political motives. Indeed, to highlight their rejection of colonialism, FLN carried out major political acts. This separatist organization which claimed responsibility for the military operations of November 1, 1954 and which, at the end of the Algerian War, established itself as a single party denying any political and cultural pluralism, ordered in May 1956 that the Muslim clubs of Algeria cease all sporting activity. The instruction was followed by sporting Algerians and artists who subsequently deserted stadiums and theaters. As inter-communal 
tensions set Algerian football ablaze, the first bombs exploded simultaneously in the stadiums of Algiers in Belcourt and El Biar on February 10, 1957 killing eleven and injuring 45. Three months later, on May 26, 1957, after attending a match with the President of the Republic Rene Coty, the former Vice-President of the Algerian Assembly, Bachaga Ali Chekkal, was assassinated at close range by Mohamed Ben Sadok at the exit of the Yves du Manoir of Colombes stadium. This attack took place in the final edition of the Coupe de France. In the final of the following edition in 1958, striker Abdelkader Mazouz, who played for Nîmes, appeared on the pitch wearing a red fez, an act of protest against French authorities.

At the beginning of the 1962-1963 season, there were 21 Algerian footballers enrolled in French clubs. They all had one thing in common: Algerian citizenship and passports from their homeland. Their political status had now changed however. No one would ever be able to consider them anymore as mere Franco-Muslims. In the eyes of France, they had now officially become foreigners. Whereas the migratory pressure of Algerian workers wishing to live in France kept growing until 1973, the migration of football players dropped year after year. ${ }^{2}$ At the same time, a fragile Algerian sports movement arose. It built upon the infrastructures left behind from the colonial period, such as the Marcel Cerdan Stadium in Alger, Bologhine in Saint-Eugene, Paul Andre at Sidi-Bel-Abbes, Greffier at Mascara and Velodrome at Annaba. In Oran, the Etienne Gay and Vincent Monreal stadiums, close to the Municipal Sports Park, continued to be active. Resuming sports activities was a hard task. It began in July 1962 with football, cycling and boxing. Friendly sports meetings and commemorative sports tournaments with Tunisian, Moroccan and Egyptian teams, were organized. This was the beginning of a new, approximately twenty year, period characterized by the nationalization of Algerian football. ${ }^{3}$ This contribution questions how the Algerian politics affected elite football. It asks also what were the consequences for sports migration between two countries linked by a long and bloody colonial history.

To answer these two questions, the analysis will combine written and oral sources collected in France, Switzerland, and Algeria, numbering about sixty interviews with former Algerian professional players born between 1914 and 1985. Thanks to a biographical pact sealed with the interviewees as well as the use of a single interview guide, the 'life story' approach brings together several testimonies on the same experience. ${ }^{4}$ It makes it possible to 'go beyond their singular experiences to achieve, by progressive construction, a sociological representation of the social and collective components of the situation. ${ }^{5}$ The objective is to compile career trajectories likely to illustrate historical transformations beyond the sporting world. This contribution is based on five successive parts: rebirth and turmoil, FLN champions return, players confined to Algeria, military players attack, and the national sports reform.

\section{Rebirth and Turmoil}

In 1962, the Algerian government legitimized itself with victory in the war of independence. They also tapped into other sources of legitimacy, such as economic development through socialism, a foreign policy of non-alignment and state control of the values of Islam. ${ }^{6}$ Independence also meant that sports could make a new 
start. Just as for schools, resources were limited; there was a lack of qualified staff. Mahmoud Abdoun, a former activist from the Algerian People's Party -Movement for the Triumph of Democratic Freedoms- and then of the FLN, thanks to his commitment to sports in the MC Alger, was charged by the FLN with an important mission. In charge of the Sports Commission, he had to establish the country's new sports structures.

Four federations were created through constituent assemblies which took place on October 21, 1962: swimming, boxing, cycling and football. The latter was headed by Hamid Bouchouk who was appointed as the National Director of Physical Education at the Ministry of Youth, Sports and Tourism. The Ministry itself was headed by Abdelaziz Bouteflika, close to Houari Boumediene, who later went on to be one of the leaders of Algerian diplomacy for about 15 years. Located on Colonel Amirouche Boulevard, the Federal Board of the Algerian Football Federation (AFF) was appointed. It was chaired by Doctor Mohand Maouche, a former star footballer from Algiers, who also presided over the Algerian Olympic Committee in $1963 .^{7}$ The first Vice-President of the AFF was the lawyer Hamid Kassoul. Its technical advisors were Marcel Bir, Jean Cosman and Marcel Wendel, former executives of the League of Algiers, temporarily in charge of the Federal Secretarial Office. Louis Rivet and Michel de Haro were honorary members. The Federation was recognised by the administration on November $15,1962 .{ }^{8}$ Starting in July 1963, through the decree no. 63-254, the Sports Charter, closely modeled after that of the Vichy regime in France, regulated the practice of sports. According to Article no. 5 of the AFF bylaws, the clubs, their leaders, and the players were to remain amateurs. The first issue of the AFF's official periodical Algerie-Football, published on January 5, 1963, guaranteed that 'any amateur Algerian player will be authorized to sign a licence in the club of his choice, regardless of his previous qualifications, in Algeria, Tunisia, Morocco or France. ${ }^{9}$ Brown amateurism prevailed. ${ }^{10}$ In its statutes, from the beginning of the 1960s, the AFF rules concerning qualifications, licences, and transfers mention that any player who was a French national, regardless of his place of birth, and who held a licence, was not counted as a foreign player admitted to play in the first team. ${ }^{11}$

On August 28, 1962, the AFF contacted the International Federation of Association Football (FIFA). In its December 3, 1962 application file, a symbol of national sovereignty, it claimed to have 27,000 players in 254 clubs (among which 96 were members of the League of Algiers). In other words, the Algerian league contained the greatest number of football players from Africa, not including the informal practice of football by youngsters. The AFF benefitted from the help of a major ally: France. Connections with the former colonial power had not been broken off. ${ }^{12}$ On the contrary, in order to help with the rebirth of football in Algeria, the former Secretary General of the Union of European Football Associations (UEFA) endorsed on October 16, 1962, the League of Oranie's application to organize in Oran a match between a selection of Algerian players and a team from the French town of Nîmes, trained by Kader Firoud. Furthermore, via its General Secretary Pierre Delaunay, the Federation Française de Football (FFF) sponsored the AFF through a letter of recommendation sent on December 26, 1962. Although a climate of violence existed within the FLN, and a prolonged civil war was narrowly avoided until the victory 
of Ahmed Ben Bella, football resumed on October 7, 1962. The championship started in Algeria as an honour criterion, regional and corporative. It generated hope and enthusiasm. At the end of the 1962-1963 season, the Championship and the Cup of Algeria were won by Abderrahmane Boubekeur's USM Alger and Hamid Kermali's ES Setif.

In 1963, the Fennecs' first international matches delighted and thrilled the Algerian people. ${ }^{13}$ Before overcoming the Federal Republic of Germany, the Algerian team played in Algiers and in Oran, against Bulgaria, Czechoslovakia, Egypt, Yugoslavia and Hungary. The spine of the Algerian team was made up of former FLN players and promising youngsters. But the level did not fulfill the AFF's and the public's expectations, despite the fact that the AFF joined the Confederation of African Football in 1964. Up until 1965, the year in which the French referee Robert Masson was sent by FIFA on a supervisory mission in Algeria, the first national coaches were Kader Firoud, Smail Khabatou, Abderrahmane Ibrir and Abdelaziz Ben Tifour. 23 professional footballers defended its colours. However, some like Abderrahmane Defnoun and Salah Djebaili, had trouble being allowed time off by their French employers. Others, such as Khennane Mahi, were injured during a game and not well looked after by the AFF. In Algeria, just like in other African countries, the football of the new nations was marked by state intervention, the refusal of professionalism, and a weak representation of its members in FIFA's Executive Committee. The politicisation of African football, the administrative laxity of certain officials, the corruption of the referees, press manipulation, the absence of statutory playing fields, and violence during games also plagued football in Algeria. The night from June 18 to June 19, 1965 was symbolic of the power of football, when, after having watched the victory of Brazil against Algeria in the municipal stadium of the City of Oran, Ahmed Ben Bella was overthrown by Houari Boumediene. ${ }^{14}$

In order to penetrate world class football, the leaders of Algeria implemented policies of cooperation, first and foremost with France, especially in the educational system and the training of executives at the National Center for Sports in Algiers and its regional branches. Maurice Baquet developed the Algerian sports system starting in 1964 with more than 11,000 French teachers. ${ }^{15}$ Women's sports also started, albeit slowly, in large cities under the leadership of a few European female trainers. After independence, French trainers also worked with former Algerian football players, and helped prepare them for professional careers. Training sessions were often carried out in Algeria. In response to a situation of emergency, Hacene Bourtal, Abderrahmane Ibrir, and Hocine Bouchache spent two weeks following the physical and sports education courses of a French trainer in October 1962. Some training sessions also took place outside of Algeria. At the Vincennes National Sports Institute, Kamel Lemoui's trainers were the highly experienced Henri Guerin and Joseph Mercier. To reinforce the ranks of US Biskra after independence, Kamel Lemoui received a monthly salary of 60,000 Francs, was given a house in the Capital of the Zibans and a job as a sports educator at the head office of the Ministry of Youth and Sports.

Foreign skills in other areas were also sought out. The July 5 Stadium was built by Bulgarian engineers and was inaugurated in 1972 in Algiers. The experience of foreign technicians from Western as well as Eastern countries, helped avoid 
inter-ethnic conflicts in a country in which significant linguistic and regional differences existed. In 1966, the French coach Lucien Leduc was appointed as the head of the Greens. Two years later, for the first time in its history, Algeria qualified for the African Cup of Nations. Made up of amateur players, Algeria was eliminated in the pool stage of the competition. Another decisive qualifying match, against Tunisia soon loomed on the horizon, this time for the World Cup. Winning was a must. Lucien Leduc placed his trust in six seasoned professional players: Rachid Mekhloufi, Madani Ben Tahar, Mohamed Lekkak, Rachid Natouri, Mohamed Salem, and Mohamed Abdelkader Tayeb. Mekhloufi, promoted as captain of the team, was unable to prevent a draw, the consequences of which were ominous. The Algerian press went wild, blaming the professionals and tensions in the locker-room. The last players who were still active, having been part of the FLN's 11 members, were forced to resign and the national team, under the influence of the USSR, turned exclusively towards amateurism. For 12 years, up until 1980, protectionism was the rule. No professional football player would wear the Algerian colours. Four players, however, broke this tacit rule: Mohamed Lekkak, Rachid Natouri, Mustapha Dahleb and Abdelghani Djaadaoui, the latter two having grown up in France.

\section{FLN Champions Return}

Among the FLN football players, at the end of the War of Algeria, players old enough to do so joined their home clubs. They still felt strongly attracted to France where they first experienced freedom. They wished to make up for lost time and enjoy once again the adrenaline and the salaries of high-level football. In their home country, insecurity still prevailed and the AFF, obsessed by amateurism, did them a favour. In France, the suspension of the contracts of FLN footballers, such as Rachid Mekloufi, was officially lifted on June 29, 1962. ${ }^{16}$ They were quickly approved and registered by the National Football League's Legal Commission: Amar Rouaï and Abderrahmane Defnoun were also approved on June 27 and July 26, 1962. ${ }^{17}$ Everything was set. Extract from the minutes of the FFF Federal Bureau Session July 21st 1962

\footnotetext{
Situation of the former professionals having returned from Algeria- The Board, taking into consideration the request from the Central Commission of the Control of Transfers; given the current situation in Algeria, agrees that the competent commission may authorize, exceptionally, and for the 1962-1963 season, to grant the right to former professionals from Algeria to be transferred, and the right for them to play in the first team. ${ }^{18}$
}

Starting with the 1962-1963 season, nine footballers returned to France: Saïd Amara to Bordeaux, Ali Ben Fadah to Toulon, Abderrahmane and Mohamed Soukhane and Cherif Bouchache to Le Havre, Abderrahmane Defnoun and Amar Rouaï to Angers, Abdelkrim Kerroum to Troyes and Ahmed Oudjani to Lens. They weren't aware that French football was undergoing a serious crisis. The edifice of professionalism in French football was threatened by the management and the mood prevailing in the clubs, the status of players challenged by the National Union of 
Professional Football Players, competition from large amateur clubs, the survival of a second division, the almost total disappearance of professional football in Paris, the public disenchantment and the weak performance of the French national team. ${ }^{19}$ Quotas drastically limited the presence of foreign players. For a short while, four other FLN players were forced to play in Switzerland: Mohamed Maouche in Martigny, Abdelkader Mazouz in La Chaux-de-Fonds, Rachid Mekhloufi in Geneva and Hamid Zouba in Granges.

This partially French-speaking country was more popular following the Franco-Algerian talks of December 1960. Many players, upon returning to Europe, spent a few days there. However, their bank accounts were almost empty. Under the responsibility of the FLN's Federation of France, in the new Algerian Consulate in Geneva, using fake Tunisian papers, Amar Rouaï obtained visas enabling him to apply to his club near Angers. To his great surprise, upon arrival, he received an envelope containing his back pay for the months of March and April 1958. Saïd Amara then flew directly from Tunis to Bordeaux with a letter of recommendation from the Deputy-Mayor Jacques Chaban-Delmas in his pocket. In El Biar, the Soukhane brothers' family reunion was interrupted by a telegram from the dean of French clubs. One month later, in August 1962, they were greeted in person at Le Havre train station by club president Andre Robert. Their resentment towards colonial oppression was now a thing of the past.

Even though they seemed to have been warmly welcomed by their presidents, the coaches and other team members, their status weighed heavily on their careers. Abderrahmane Soukhane was for six years undeniably a member of the port city of Toulouse and then of the Red Star teams. In Le Havre, he negotiated a pay raise, for himself and his elder brother Mohamed. In Saint-Etienne, Rachid Mekhloufi scored 14 goals in 20 matches, during the last part of the 1962-1963 season, and then won three times the title of Champion of France and a French Cup title. As far as Ahmed Oudjani was concerned, after two disappointing experiences with JSM Tebessa and JSM Bejaïa, he thrived in the North of France. 'Medo' was loved by the inhabitants of Lens, having adopted the customs of the local workers' community. Off the field, the top scorer of the 1963-1964 championship readily took part in the discussions animating the town streets and cafes. ${ }^{20}$ Their remuneration was the focus of heated discussions. When he found out the amount, Amar Rouaï strongly reacted. He expressed his disagreement to the President of the Angers Club Jean Samain who then housed him on Plantagenet Street, then on Figuier Street: 'I want a high salary, just like the club's best player, or else I'll go back home to Algeria. There's a position awaiting me there as a trainer or an executive in the Youth and Sports Ministry. ${ }^{21}$ Finally, his demands were met.

In 1962, the presence of these football emigres in French stadiums was embarrassing. It sometimes turned into an ordeal in a country torn by deep-seated racism related to the institutions and the practices of the French colonial empire. ${ }^{22}$ Mockery from other team members, fear of former French Algerian settlers (called Pieds-noirs) and of the Secret Army Organization (OAS), and the insults pouring down from the stands all generated a great sense of unease. ${ }^{23}$ In Troyes, Abdelkrim Kerroum wasn't housed in a beautiful home as he had previously been in 1960, but was instead placed in a cheap development building. Like several others, Saïd Amara 
found threatening letters sent to his home. The Algerian players started becoming weary of the abuse they received in towns in the South of France where large numbers of repatriates intimidated them physically. Progressively, Algerian football players started leaving France. Their careers were nearing the end at a time when French professional clubs rushed to hire international stars in order to fill the stadiums with larger crowds. During the 1966-1967 season, there were only 13 professional Algerian players in France. ${ }^{24}$ Feelings of nostalgia for their home country and calls from the Algerian authorities had a definite influence on them. The possibility of playing more easily as members of the national team and to retrain also had a strong effect upon them. In Algeria, the possibility of earning a living from playing football was enticing. In 1963, against the wishes of the FFF, some contracts were bought back by the AFF. For 6,000 old Francs, Amar Rouai recovered his freedom as a player and took over USM Bel-Abbes. Abdelkrim Kerroum coached MC Saïda. Mohamed Maouche played for and coached ES Mostaganem. Abdelkader Mazouz held two similar roles with USM Blida. The following year, with the promise of a bonus and of a beautiful house in Hydra, overlooking Algiers, Abderrahmane Defnoun became player-manager at NAHD, making use of skills he had learnt in Angers in 1963 on how to physically prepare athletes.

After returning from Bordeaux, Saïd Amara, a member of MC Saïda, took part in workshops in Oran in 1964 and also became a regional football coach. Promoted at the same time as Henri Biancheri, Aime Mignot and Ladislas Nagy, he earned a degree to become a coaching instructor on July 3, 1968 in Vincennes. The conclusions of the national instructor Georges Boulogne were final: 'a valuable workshop, especially technically and pedagogically. Progress still needs to be made concerning general culture as well as talking skills. ${ }^{25}$ Training became the main work of these ex-players until the 1980s. Their influence on national selections, the national technical management and the Algerian clubs was marked. After having been trained in France, each one of them ended up sitting on four different sidelines.

Right after independence, Algeria granted travel exemptions to its FLN footballers. Free to move around, their devotion was honoured and rewarded. In contrast, young Algerian players were systematically blocked by the AFF from signing professional contracts abroad. For these young football hopefuls, borders between Algeria and France were closed. Any desire to leave was opposed by the Ministry of Youth and Sports (MJS). They were forbidden from emigrating abroad to become football professionals. This practice was in total contradiction of FIFA regulations, which advocated freedom of movement for football players. However, FIFA regulations contained two stipulations; every football player had to have a letter authorizing their departure from their former club and an international transfer certificate from their home federation. Much to their regret, Algerian footballers were considered as assets, and just like agricultural lands, were nationalized accordingly.

\section{Players Confined to Algeria}

The Algerian State claimed ownership of sports. Its intervention took three main directions: physical and sports education, which became mandatory in 1968, the civil and associative sector remodeled in 1971, and exporting footballers. Just as in 
other African countries such as Zaïre under the rule of Joseph-Desire Mobutu, demagogically and without respecting individual liberties, transfers became a state business. Football was the source of popular and exuberant passions. The clubs were headed by austere and omnipresent colonels. Their paternalism ensured both protection and submission. Manipulations were rampant. Once again, nationalistic unanimity was the required standard. The migrations of the sports elite were powerful political stakes. ${ }^{26}$ Through a state-controlled federation, football was seen in Algeria as a catalyst of the national sentiment, a tool for generating social peace and a way to assert one's personality. Reporting to the MJS, the AFF refused professionalism while keeping its most gifted members hungry for the West.

In the FIFA archives consulted by historians Pierre Lanfranchi and Matthew Taylor, the AFF sent an unequivocal letter to FIFA on November 24, 1964. The Dinar had just been created and the message was clear: 'we regret to tell you that following the decision of our state secretary of Youth and Sport, the Federation has decided to take every step to terminate the departure of our young players abroad and therefore we will not give any clearance certificates. ${ }^{27}$ Without any international transfer certificate from the AFF, the Algerian clubs' departure letters were worthless. Hundreds of players such as Benaïssa Braïk and Tahar Benferhat, captain of JSM Tiaret and of the Greens, saw their dreams shattered. As his case became more political, Ahcene Lalmas, the greatest Algerian player post-independence, was compelled to refuse overtures from European Clubs such as Saint-Etienne AS, Barcelona, and AC Milan. A star of CR Belouizdad with whom he won four titles and three Algerian Cups from 1965 to 1970, 'El Kebch' prefered to live comfortably in Algiers. A close friend of the former football player Paul Sadat, Hamid Bellabes, was exceptionally freed by the AFF after three years. From a more well-off family, the MC Oran attacker finally managed in 1966 to convince President Mohand Maouche to let him play for one season as an intern-professional at Stade Français during his economy studies in Paris. Others were not as fortunate as Bellabes, not having similar academic pedigrees or not having been acclaimed by supporters from Ajaccio, Beziers or Chaumont, such as Kader Aïssat, Mohamed Haddi and Habib Zahaf.

In Algeria, the absence of any kind of democratic legitimacy was blatant. The army was a ruling and violent class dominated by Military Security. ${ }^{28}$ The way the state handled the tricky Ali Bencheikh case illustrated the way in which Algerian authorities used terror as a strategic tool to get people to obey. Playing with MC Alger, Bencheikh won every possible prize and distinction. Champion of Algeria in 1975, he soon became an international hope, making his debut at only 19. In 1976, aged 21, coached by Hamid Zouba, he won the African Cup of champion clubs, to which was added the Algerian Championship and Cup. 'Alilou' was one of the most successful Algerian footballers of the 1970s. A serviceman in the national armed forces and one of the leaders of the national team, he responded favourably to FC Nantes' offer and crossed the Mediterranean in the summer of 1978. Blocked by the AFF, however, he was forcefully repatriated by agents of Algeria's secret service. He regretted this:

...my successful trial performance in Nantes ended with meeting the club's leaders. They wanted me to sign documents in order to quickly become a French citizen. I replied that I needed to think it over. After one night's sleep at Hotel Normandie in Paris, I got up early and strolled in the streets of Paris. Around Opera Square, an unmarked 
Renault 30 car stopped near me. Three guys got out immediately and introduced themselves as members of the Algerian Consulate. I immediately understood that they were members of the Military Security Forces, whom everyone fears. I followed them. They told me that President Boumediene had ordered me to go back home to Algeria in order to prepare for the African Games. I did as I was told. I was still young. They escorted me back to the hotel and then on to the airport. ${ }^{29}$

As he got off the plane, two governmental agents took him to an apartment. He returned to El Khadra, run by Rachid Mekhloufi, and won the African Games at home. After that, Ali Bencheikh tried once again to leave Algeria but was intercepted by a customs officer who shared with him troubling news. President Houari Boumediene had banned him from leaving the country. His two unsuccessful attempts to leave the country reflect how the Algerian State used police forces to control football players after 1962. His story shows how the authorities sometimes offered the carrot - a privileged lifestyle in decolonized Algeria - and sometimes the stick - the threat of repression. In April 1979, all Algerian citizens were banned from leaving Algeria. A certain number of them, such as Mohamed Henni who had left for the town of Limoges in France in 1973, were ready to sneak through the border once again and tackle new sports challenges, even if it involved a degree of risk. For the AFF, plagued by favouritism and perhaps also corruption, players such as Nasser Guedioura were the most precious. As early as 1977, aged only 25, the swift left winger from Jeunesse Sportive de Kabylie (JSK) (Kabylie Region Sports Youth), Abdellah Djebbar, was freed by the AFF and authorized to join the town of Chaumont's second division Club.

From 1975 to 1979, six additional international Algerian players secretly left for Europe. Most of them had done their military service, instituted since 1968, at the Beni-Messous Sports Center and its regional branches. Aged about 27, they were ready to make a living from playing football, and leave behind their ailing clubs in Algeria. By leaving for Europe in a context of uncertainty, these players also left their national team for good. FIFA regulations were also in their favour. Despite the absence of official Transfer Certificates, they became officially qualified to play in the French football championship after one year. Rheda Mohamed Ali Messaoud, Zoubir Bachi, Rabah Gamouh, Nasser Oughlis and Djamel Tlemçani played for more than three seasons in France and in Belgium, most often in the second division. Individual initiatives and scouting missions in Algeria by French sports directors such as Daniel Ferrand from PSG facilitated their departure. Some of them were fortunate enough to be spotted by the Portuguese agent Lucidio Ribeiro and advised by former professional footballers. ${ }^{30}$ Djamel Tlemçani was helped by Max Sellal, who had become a dental surgeon in Algiers, and who handed him a letter for the Nîmes trainer Rene Vernier. With barely 300 Francs in his pocket, the future was his. However, only Rabah Gamouh and Djamel Tlemçani made a lasting and significant impression on France football, taking part in World Cup qualification. ${ }^{31}$ Most of the other players in this group had contrasting fates and returned to anonymity in their native country.

To try and restrict these sports migrations, the AFF reacted in two distinct ways depending on how interested it was in a given player. The AFF did not always reply to letters from FIFA and often played for time. Rather, it opposed itself firmly in 
writing to these transfers, such as in the case of the transfer of Djamel Zidane whose unwavering determination was revealed in FIFA's archives. His trajectory revealed his determination to migrate despite all prohibitions. In 1976, aged 21, he signed for a season in the town of Corbeil-Essonnes as an amateur player. He obtained a one-year residence permit from the Paris Police Prefecture (administrative office) and signed up to the University of Vincennes to start studying law. He was then approached by several Belgian clubs who all appreciated the way he played during tournaments with the junior national teams and who were about to lower their quotas granted to foreigners. He wrote on July 23, 1977 in Zurich: 'my membership was accepted by the Belgian Federation on a temporary basis, but the Algerian Federation refused this transfer, despite the fact that my Club, USM Alger, had agreed. By staying inactive for one year, I had thought that I would be free to play during the 1977-1978 season. I have the honour of submitting this case to your appreciation in order to obtain a favorable outcome. ${ }^{32}$ Since the AFF's Secretary General refused to let Djamel Zidane go, stating as much in two letters sent to the Belgian Federation on October 23rd and to FIFA on November 26th. FIFA had to take a stand. On December 1, FIFA replied to the AFF saying that it regretted its unacceptable attitude and officially qualified the player to play in Belgium. The AFF had no legal grip on him thereafter. Finally free, he stopped studying at Brussels Free University and dedicated himself entirely to football. From 1977 to 1986. Zidane played for Eeklo, Saint-Nicolas, Courtrai and Waterschei.

Each of these footballers who left Algeria discreetly, such as Abdelkader Radaoui, say they have kept positive memories of their professional career, thanks to the comradeship in their clubs and a lavish lifestyle. However, they also recollect how they were sometimes reminded of their status as sports immigrants, for example striker Sofiane Meziani, who navigated through the Algerian, Belgian, French, and German championships from 1981 to 1996. Cheap imports, they often earned 20 to 30 per cent less than their locker room companions despite being of equal experience and skill. Nasser Oughlis also remembers the strategies of the Caen chairman to keep him at the end of the 1970s. With his connections in the Paris Police Prefecture, Oughlis was only ever given a one-year renewable residence permit, instead of a 10 -year permit. $^{33}$

\section{Military Players Attack}

At the beginning of the 1970s, at a time when players such as Larbi Boussa, Mohamed Lekkak, Ahmed Oudjani, and Mohamed Salem were ending their long sports careers, Algeria was in the midst of a period of industrialization. Pipelines and natural gas were nationalized in 1971 and rulings and charters for the agricultural revolution and the socialist management of corporations were enacted. As compared to other Maghreb (North-Western African) States, the country chose a militant and revolutionary brand of socialism, for the most part inspired by the emerging Third World Soviet model. ${ }^{34}$ In the area of sports, Rachid Mekhloufi, player-coach of Bastia (Corsica), was appointed in 1970 by the FLN as Sports Director in the Ministry of Defense. At 34, his mission was to create with his friend and aide Mohamed Soukhane the first Algerian military national football team. After a 13 month 
experience overseeing the Algerian selection process and team, cut short for lack of results, he returned to the Ministry's offices and his military uniform. Everything was once again re-launched for military sports. Discipline and solidarity shaped its identity from that point on.

To make up a competitive military team, Rachid Mekhloufi could count as early as 1972 on his friends Amar Rouaï, Hamid Kermali and Abdelkader Mazouz, as supervisors. The country's most talented football players were called to the barracks of Beni-Messous. Their enrolment conditions were not the same as their elders had experienced in France in the 1950s. Indeed, after a few weeks of instruction, the long trainings and travels abroad rewarded with a few bonuses were part of a two-year programme. There was also rigorous discipline, submission to authority and sanctions. Djamel Tlemçani never forgot the long nights spent in a cell inflicted by trainers. Caught up by football, all these youngsters progressed in sports. In a position of power, Rachid Mekhloufi did not want to miss the Mediterranean Games in Algiers, an event which enabled Algeria to reinforce its driving role in Africa, with respect to non-alignment, the Organization of Oil Exporting Countries (OPEC), and firmness with regards to Israel. In 1975, the military national team arbitrarily replaced the civilian selection; the brutal eviction of tenured players such as Selmi Djilali, key striker of CR Belouizdad, was inevitable. The military players entered a sports competition that was not intended for them. ${ }^{35}$ The former striker from AS Saint-Etienne tells the story of his success which gave Algeria its first international title against France led by Michel Platini:

....in the month of June 1975, after the AFF Board and the National Team, led by Makri, had been dissolved, I was called upon by the highest authorities and Boumediene to prepare the 11 nationals for the Mediterranean Games planned in September, which Algeria was supposed to organize. I have to admit that I was kind of expecting that decision. Except for Omar Betrouni, I replaced the entire national team by my national military team with which we had already been working for the past three years. Algeria won the Gold Medal, beating the French amateur team. ${ }^{36}$

This victory by Algeria was celebrated by the Algerian people as if the country had become independent for a second time. In 1976, the Algerian Constitution was approved by a referendum and Houari Boumediene was elected as the President of the Republic. After his success, Rachid Mekhloufi was confirmed in his role as the national coach. In 1978, a new victory at home occurred when the team led by a determined Ali Bencheikh won the African Games. Empowered by the President's support, he entrusted the other national teams to his right-hand men. Management was united as it never had been previously. Each went out to find the most promising football players of the time. Mohamed Soukhane was in charge of the members of the military, Hamid Kermali of the juniors, Amar Rouaï of the cadets, and Abderrahmane Soukhane of administrative coordination.

These former professional players passed on their knowledge to younger ones, such as Lakhdar Belloumi, Rabah Madjer, Chabane Merzekane and so many others who would later stand out for Algeria in future World Cup tournaments. The way the players were selected was drastic however. Allowed to return to their respective clubs from Thursday to Saturday, they were also coached by former professionals 
such as Saïd Amara, Kamel Lemoui, and Mohamed Maouche. In the army, friendly games and commando workshops accumulated. The military plane was flying full time and the first trips abroad delighted the players. The way they played during the international tournaments of Auxerre, Cannes, Lille and Roubaix have lived on in their memories. They viewed France as an eldorado for sports, despite the fact that they were not allowed to become professionals there. As early as 1976, the Algeria of Salah Assad, Ali Fergani, and Mahmoud Guendouz played a prestigious friendly match in Paris with its home team. In 1979, Hamid Kermali was at the head of the junior team which won the African Cup of Nations. But that same year also saw the unexpected resignations of Rachid Mekhloufi, Amar Rouai and the Soukhane brothers in solidarity with the removal of Djamel Houhou by the Ministry of Youth and Sports. Yet this did not change anything. Algerian military and civilian football was already structured and this reinforced the skills and migratory ambitions of its Algerian football players subjected to a new socialistic PSE (Physical and Sports Education) Code as of 1976. As soon as it was introduced, such a code reminded these high level practitioners that they had to benefit from definite socioprofessional adjustment measures, rather than privileges, in strict compliance with the rules of amateurism. ${ }^{37}$

On June 19, 1977, in the July 5th Stadium, during the Cup of Algeria finals between JSK and NAHD, the national anthem was intensely hissed down by Kabyle supporters. The President Houari Boumediene and the members of his government did not allow such an insult to national cohesion to go unpunished. Denounced as a poor example to young people, professional sports were subjected to a far-reaching reform enacted by the Council of Ministers on June 27, 1977. Sports migration policies were modified as a result.

\section{The National Sports Reform}

Public corporations entered Algerian football in 1977. Clubs were dissolved and replaced by Associations Sportives de Performance (ASPs) -Sports Performance Associations. Connected to schools and universities, there were 391 ASPs in 1981 and 699 in 1983. They were financed and staffed by socialist companies, the only sector that offered any financial resources who recruited the great majority of high performance athletes by adapting their profiles to the available positions. ${ }^{38}$

With local sports associations, this institutional integration of performance sports into the productive sector also resulted in the opening of sports schools and in changes in the acronyms previously used to name the clubs. They started to be very close to the names of their sponsoring firms. Thus, MC Alger, sponsored by SONATRACH whose financial power was huge, became Mouloudia des Petroliers d'Alger - Mouloudia of the Algiers Petroleum Producers, thus avoiding any reference to any regionalism. Monitored by the authorities, JSK was re-named in 1977, the year of its double Cup-Championship victory, as Electronic Youth from Tizi-Ouzou - Jeunesse Electronique de Tizi-Ouzou (JET). ${ }^{39}$ Another example, in Algiers, USM was renamed US Kahraba. The living conditions of the players also improved. US Kahraba centre forward Nasser Guedioura for example became a salaried employee, started studying computer science, received bonuses, took 
holidays abroad, and did not have to pay gas nor electricity in the house he shared with his wife.

In Algeria, volunteering was frowned upon, sponsoring and patronage were illegal. The benchmark model was that of the USSR and of Cuba, with whom cooperation developed. Soviet executives taught in brand new Institutes of Sciences and Technology. Russian physicians abounded in Algerian sports. ${ }^{40}$ Between 1978 and 1986, MJS's budget went from 267,000 to 446,000 dinars. Its responsibility was to train sports executives and high-level coaches. Integrated in their powerful corporations despite their real needs, football players benefited from professional training to insure their future. Unofficial sports professionals, they perceived themselves as civil servants. Mahmoud Guendouz, advocate of the Societe Nationale des Transports Maritimes, formerly NAHD - National Sea Transport Company - shared what were his new working conditions. As with others, his advantages were striking:

Overnight, I'm not payed in an envelope anymore. At the end of the month, I receive my salary and bonuses for the matches. I only play football, not to mention national selections during which we work overtime. The State helps us by offering to us, depending on our results, cars, land, shops and apartments. I also have the possibility of following computer training. ${ }^{41}$

From that point on, Algerian football was streamlined: now recognized, players had comfortable accommodation and chauffeurs to drive them to the stadium. Their initial level of studies ensured them positions as employees or executives. In reality, they were paid to play football. Each and every day, they would practise, train, go out for lunch, and enjoy refreshing naps. International football players got additional bonus points on their wage slips. Careers in Algeria thus became more and more attractive. The level of football improved, which delighted all the former football players who were coming back home to Algeria. This 1977 sports revolution, combined with the rise of military football, opened up a golden era in Algerian football and the rewards were soon apparrent. Algerian clubs such as Mahieddine Khalef's JET won the Algerian Cup-Championship treble and the African Championship title in 1981. Besides the 1978 African Games, the national team won the African Cup of Nations and reached the quarter finals of the 1979 Junior World Cup. Algeria's fourth place during the Mediterranean Games in Split in 1979 was also momentous. The national team went on to achieve second place in the 1980 African Cup of Nations and reached the quarter finals of the Moscow Olympic Games. In 1982, as a semifinalist in the African Cup of Nations, the Algerian national team prepared for its first World Cup, although this was also a period marked by controversy. The AFF, who had signed a sponsoring and provisioning of sports supplies deal with Puma amounting to four million francs, got caught red-handed for unfair competition. Abdennour Bekka, Minister of Youth and Sports, former Director of military sports and chairman of the AFF, insisted that the Fennecs wear Sonitex clothing - Sonitex being the national textile Company - except for shoes and socks. 20 years after independence, the Socialist State wanted to celebrate its individual successes thanks to sports.

Football players also enjoyed new-found freedoms guaranteed by this reform. Once their military service was over, and provided they were at least 28 years of 
age, some of them were allowed to work abroad. Despite the fact that no regulation officialized this practise widespread in other socialist countries, this was confirmed by all of the interviewees. In 1979, Khelifa Benmessaoud, a 28 year-old striker, arrived in Caen thanks to a fervent supporter who recommended him to President Emile Santais. Nearing the end of his career at the National Algiers Construction Management Sports Club, wishing to become a student, he had no difficulty convincing the AFF to let him go.

After independence, the nationalization of Algerian Football was brutal. After 1962, the clubs and the national civil and military teams were strictly controlled by the state and by AFF. For political reasons related to national prestige, this affected the migration of Algerian players abroad as well as the selection of players for the national team. Nevertheless, among Algerian sportsmen, the attractiveness of the Championship of France remained potent and the desire for Algerian football players to emigrate remained constant. 20 years after the independence of Algeria, professionalization that allowed young Algerian internationals control of their careers happened after the 1982 World Cup. Wishing to take advantage of the surge of renewed confidence and support from Algerian citizens, President Chadli Bendjedid surprised everyone when he authorized new transfers. Then Minister of Youth and Sports, Abdennour Bekka publicly stated that the Algerian national team's victory over West Germany did more for the nation than any ambassador in the world. On July 26, 1982, he recalled the transfer rules: European clubs must negotiate directly in Algiers with the AFF. Thus, it exceptionally allowed a few champions to become professional in France and put an end to sports protectionism. Expatriation no longer implied a more or less definitive break with the country of origin. Aged 24, Salah Assad, the Raed Chabab Kouba's striker, nominated as the World Cup's best left winger, was the first player who was officially allowed to leave Algeria.

\section{Notes}

1. Tramor Quemeneur and Slimane Zeghidour, L'Algérie en Couleurs, Photographies d'Appelés pendant la Guerre d'Algérie 1954-1962 (Paris: Les Arènes, 2011), 191-99.

2. The December 27, 1968 Franco-Algerian Treaty limited the freedom of movement which the Evian Agreements had previously guaranteed. Border control became more strict and more selective than previously. On September 20, 1973, President Houari Boumediene banned emigration towards France.

3. According to lawyer Olivier Beaud, 'nationalization is the result of a voluntary act of public power by which the State, for reasons of economic policing, transfers directly to its profit the ownership of companies previously held by private persons'. Thus, the State expresses its sovereignty'. Olivier Beaud, 'Nationalisations et Souveraineté de l'État', Histoire@Politique. Politique, culture, société 24 (2014): on line, https:// www.histoire-politique.fr/documents/24/dossier/pdf/HP24_Dossier_Olivier_Beaud_ def.pdf

4. François Dosse, Le pari biographique, écrire une vie (Paris: La Découverte, 2011).

5. Daniel Bertaux, Les récits de vie, perspective ethnosociologique (Paris: Nathan, 1997).

6. Benjamin Stora, Histoire de l'Algérie depuis l'Indépendance 1962-1988 (Paris: La Découverte, 2001).

7. Mahfoud Amara, The Olympic Movement and the Middle East and North African Region (Londres: Routledge, 2019). 
8. Fonds CNO, entrée Algérie, dossier 'Correspondance 1962-1972', Archives du Comité International Olympique, Lausanne, Suisse.

9. Fonds Algérie-Football, entrée FOL-JO-17032 1962-1965, dossier 'Qualification, licences et mutations de la saison 1962-1963’, 5 janvier 1963, 5, Archives de la Fédération Algérienne de Football, Bibliothèque Nationale de France, Paris, France.

10. 'The brown amateur is an athlete who is unofficially paid, without a professional contract or who is recruited with a job of convenience. Thierry Terret, Histoire $d u$ sport (Paris: Presses Universitaires de France, 2007).

11. Fonds Correspondances avec les associations nationales, dossier 'Algérie 1962-1983', Archives de la Fédération Internationale de Football-Association, Zurich, Suisse.

12. Yvan Gastaut, 'Algérie-Allemagne, la Victoire des Héritiers du "11 de l'Indépendance" lors de la Coupe du Monde 1982', in Histoire Politique des Coupes du Monde de Football, ed. Paul Dietschy, Yvan Gastaut, and Stéphane Mourlane (Paris: Vuibert, 2006), 295-310.

13. The Algerian national team is nicknamed 'the Greens', 'El Khadra' or 'the Fennecs', in reference to the cunning desert fox.

14. Abdelkader Djemaï, Le Jour où Pelé (Paris: Le Castor Astral, 2018).

15. Maurice Baquet, Méthode sportive, initiation et entraînement (Paris: L'Harmattan, 2000).

16. Fonds Correspondances avec les associations nationales, dossier 'Algérie 1962-1983', Archives de la Fédération Internationale de Football-Association, Zurich, Suisse.

17. L., Jullian, 'Homologation de Contrats', France-Football Officiel, July 10, 1962, 3. ; L., Jullian, 'Homologation de Contrats', France-Football Officiel, July 31, 1962, 3.

18. Anonymous, 'Extrait du procès verbal de la séance du 21 juillet 1962 du Bureau Fédéral', France-Football Officiel, July 31, 1962, 2.

19. Pierre Lanfranchi and Alfred Wahl, Les Footballeurs Professionnels des Années 1930 à nos Jours (Paris: Hachette, 1995).

20. Marion Fontaine, 'Les Oudjani et le "Club des Gueules Noires": Parcours et Représentations (années 60-80)', Migrance 29 (2008): 91-7.

21. Interview with Amar Rouaï, 29 octobre 2007, Annemasse.

22. Saïd Bouamama et Pierre Tévanian, 'Peut-on parler d'un Racisme Post-Colonial ? 1961-2006', in Culture Coloniale en France, ed. Nicolas Bancel, Pascal Blanchard, and Sandrine Lemaire (Paris: CNRS Editions, 2008), 651-61.

23. Evelyne Lever, 'L'OAS et les Pieds-Noirs', in L'Algérie des Français, ed. Charles-Robert Ageron (Paris: Editions du Seuil, 1993), 223-47.

24. Hamid Bellabes, Madani Ben Tahar, Sadek Boukhalfa, Mohamed Haddi, Mohamed Lekkak, Khennane Mahi, Rachid Mekhloufi, Mohamed Mezzara, Rachid Natouri, Ahmed Oudjani, Abderrahmane Soukhane, Mohamed Abdelkader Tayeb et Habib Zahaf.

25. Fonds Jacques Georges, entrée 2004 026-066, dossier 'Brevet d'Etat d'entraîneur-instructeur de football, observations générales de Georges Boulogne', Archives Nationales du Monde du Travail, Roubaix, France.

26. Paul Dietschy, 'Les Migrations des Footballeurs: un Enjeu Politique' [Football player migrations: A political issue], Migrance 22 (2003): 92-101.

27. Pierre Lanfranchi and Matthew Taylor, Moving with the Ball, the Migration of Professional Footballers (Oxford: Berg, 2001), 174.

28. Pierre Vidal-Naquet, 'L'Algérie, Société Militaire? Réflexions sur Trois Moments d'une Histoire: 1958, 1988, 1998' [Algeria, a military society? Reflections on three moments in history: 1958, 1988, 1998], in L'Algérie Contemporaine, Bilan et Solutions pour Sortir de la Crise [Contemporary Algeria, taking stock and considering solutions to solve the crisis], ed. Gilbert Meynier (Paris: L'Harmattan, 2000), 169-84.

29. Interview with Ali Bencheikh, August 1, 2006, Alger.

30. Stanislas Frenkiel, Une histoire des agents sportifs en France, les imprésarios du football 1979-2014 (Neuchâtel: CIES Editions, 2014).

31. Jean-Charles Scagnetti, 'Coupe du monde 1982: les internationaux algériens et leur équipe nationale', Migrance 29 (2008): 45-58. 
32. Correspondances avec les associations nationales, dossier Algérie 1962-1983, Archives de la Fédération Internationale de Football, Zurich, Suisse.

33. Paul Dietschy and David-Claude Kemo-Keimbou, LAfrique et la Planète Football (Paris: EPA Editions, 2008).

34. Mahfoud Amara, 'Sport and Algerian Nationalism in the "Global" Era: within and beyond the Nation State', Francophone Postcolonial Studies 1 (2006): 88-115.

35. It is made up of Abdelmalek Ali Messaoud, Habib Benkada, Omar Betrouni, Mehdi Cerbah, Aïssa Draoui, Abdelkader Horr, Abdelkader Ighili, Djamel Keddou, Rabah Menguelti, Mourad Naïm and Abdelaziz Safsafi.

36. S. Amine, 'Rachid Mekhloufi rompt le silence' [Rachid Mekhloufi breaks his silence], El Hadef, March 22, 1987, 14.

37. Code de l'Education Physique et Sportive, October 23, 1976 (ordonnance no. 76-81), 13.

38. Youssef Fatès, 'Sport et politique en Algérie, de la période coloniale à nos jours' (Thesis in Political Science,University Paris I, (2002), 667.

39. Youssef Fatès, 'La Jeunesse Sportive de Kabylie: entre sport et politique', Awal 25 (2002): 65-73.

40. In November 2011, against the backdrop of a family drama, a scandal shook Algerian football. Breaking the omerta, Mohamed Chaï, Mohamed Kaci-Saïd and Djamel Menad called a press conference and became spokesmen for their former team mates. These international players mentionned publicly the connection between the vitamins and medication which they used during training sessions and the birth of their highly disabled children. Had they been unknowingly doped by their Soviet doctor? Since their medical files have disappeared, a terrible doubt subsists.

41. Interview with Mahmoud Guendouz, July 25, 2006, Alger.

\section{Disclosure Statement}

No potential conflict of interest was reported by the author.

\section{Notes on Contributor}

Stanislas Frenkiel, $\mathrm{PhD}$ is the Head of Collection Cultures Sportives at Artois Presses University in Arras, France. His research focuses in particular on sports migrations from colonial times to the postcolonial era. 